\title{
シーケンシャル・ファンクション・チャート $(\mathrm{SFC})$ の タイヤ製造工程への応用 ${ }^{\dagger}$
}

\author{
國 分 孝 夫*・神 山健 三**・浜 野 順 一***
}

\section{Application of Sequential Function Chart to the Tire Industry}

\author{
Takao Konubu*, Kenzou KamiYama** and Junichi Hamano***
}

\begin{abstract}
This paper describes the application methodology of SFC (Sequential Function Chart) to machines' controls in the tire industry.

With the marvelous progress of micro processing and computer technology, PCs (Programmable Controllers) have become popular and indispensable equipment for machines' sequential control in FA (Factory Automation) area. The complexity and flexibility of machine control relies advancements in PC programming technology. But most of their programs are written by old fashioned Ladder Diagram, which was originally developed as an analogy of wiring circuits. The increasing volumes of programming have revealed major inherent deficiencies in Ladder Diagram. These deficiencies are manifested in programs that are so voluminous and complex that they are practically unmanageable. To overcome these problems, the SFC has been applied as a substitute of Ladder Diagram. Originally the SFC itself has several problems in practical applications. One of the most difficulty in SFC is explanation of interlocking conditions for actuators.

In this paper, authors propose the application methodology of hybrid control by SFC and Ladder Diagram. After evaluation in more than 100 machines, and over 10 kinds of machine applications, the methodology of this hybrid control is proved to be powerful both in machine control and programming. As a result, SFC has a distinct effect on machine controllability, requires less design and maintenance manpower, reduces program and documentation size, eases checkout and start-up work, and saves training time for new personnel.
\end{abstract}

Key Words: PC (Programmable Controller), FA (Factory Automation), SFC (Sequential Function Chart), ladder diagram

\section{1.はじめに}

製造業におけるファクトリ・オートメーション(FA)の

† IECON'90 (1990・11), IECON'92(1992・11)で一部発表

* (株)ブリヂストン電気制御開発部 小平市小川東町 $3-1-1$

** 宇都宮大学工学部 宇都宮市石井町 2753

*** (株) 日立製作所生産技術研究所 横浜市戸塚区吉田町 292

* Automation Controls and System Development Department, Bridgestone Corp., Kodaira

** Faculty of Engineering, Utsunomiya University, Utsunomiya

*** Production Engineering Research Lab., Hitachi, Ltd., Yokohama

(Received December 2, 1993)

(Revised April 12, 1994)
分野で活用されてきたシーケンス制御の応用は，製造ラ インの固有技術, ノウハウの蓄積として進展してきたた め, フィードバック制御ほど理論的，体系的な解明が行 われていない. しかし，マイクロプロセッサ技術を応用 した制御装置, PC(Programmable Controller)が出現 し,さらに量産による低コストと品質向上により広く導 入されるようになると，従来のリレーを主とした配線方 式のシーケンス制御がプログラムで置き換えられた.こ れにより，製造ラインのシーケンス制御も次第にソフト ウェアを主体とした設計技術として扱われるようになっ た.

ところで，PCで圧倒的に採用されているプログラミ ング言語は，ラダー図方式であり，従来の展開接続図に 慣れた現場の作業者に容易に受け入れられ発展してきた 
経緯のものである。しかし，そのプログラムの記述形式 は PC 内部のマイクロプロセッサの処理方法と無関係で あり，制御対象の状態や制御ステップの進行を表現する のにも適した表現ともいい難い。これがラダー図方式の プログラミングに能力的限界を与える要因となってい

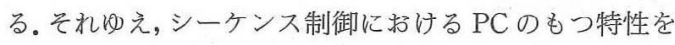
十分に発揮させる優れた効率の良いプログラミング言語 の出現が強く期待されている。このような観点から，筆 者らは，新しいプログラミング手法を提案し，タイヤ製 造工程への適用の中で評価，改良を続けてきた12,2)。

本論文では，このニーズに応元る次世代のプログラミ ング言語として SFC(Sequential Function Chart)を テーマに，その実用化のための設計手法，プログラミン グ方法を提案するとともに, タイヤ製造工程での実施結 果の評価加らその有効性を検証する。

\section{2. タイヤ製造工程と PC 活用の背景}

タイヤ製造プロセスの特徵は, 自動工程と手作業工程 との混合である。一般的に Fig. 1 亿示すように主な夕イ ヤ製造工程は,つぎの構成となっている. (1)コード工程, (2)ゴム練り・押出し工程, (3)ビード工程, (4)成型工程, (5)加硫工程, (6)仕上・検査工程 ${ }^{3}$.

それぞれの工程の役割については，コード工程では， スチール, テキスタイル・コードを準備し，タイヤの骨 格となるプライとベルトを作る.ゴム練り・押出し工程 では，天然ゴム，合成ゴムを原料にカーボン，硫黄，才
イルなどを混ぜ合せ，その形を整えタイヤの各部材ゴ ムを作る。ビード工程では, スチールワイヤにゴムコー ティングを施し，これを巻取りビードを作る。成型工程 では,これら全ての部材を組立てて生(未加硫)タイヤを 作る。加硫工程では, 生タイヤに熱処理を施しトレッド パターンがついた最終形態のタイヤができあがる。仕 上・検査工程では，品質テェックが行われる。

タイヤ製造ラインは，多種多様な部材の生産用途別に 専用の生産設備, 特殊機械が組み合されて配置されて いる。また，高度に自動化されほとんど無人に近い工程 も西る。一方，熟練作業による手作業の工程も依然残つ ている。このような生産設䚚から構成されるタイヤ製造 工程における機械制御の設計，改善，改良は，個々の機 械ごとに行う必要があり，沉用化が難しいため時間とコ ストを要する場合が多い。さらに, 近年の自動車の高級 趣向, 高性能化のニーズに応えるため, タイヤ製造機械 の制御に対してもより高速で, 複雜な機能が要求されて いる。PCはこのニーズに柔軟に対応できる制御装置と して広くタイヤ製造工程で応用, 活用されてきている。

\section{PC プログラミングの問題点と解決策}

\section{1 ラダー図方式の限界}

PC が広く用いられ，制御の規模も大きくなるにつれ， そのプログラミングに用いられるラダー図方式の限界は ますます顕著となり，機械制御を担当する技術者，保全 員を悩ます課題となっている。ラダー図方式における限

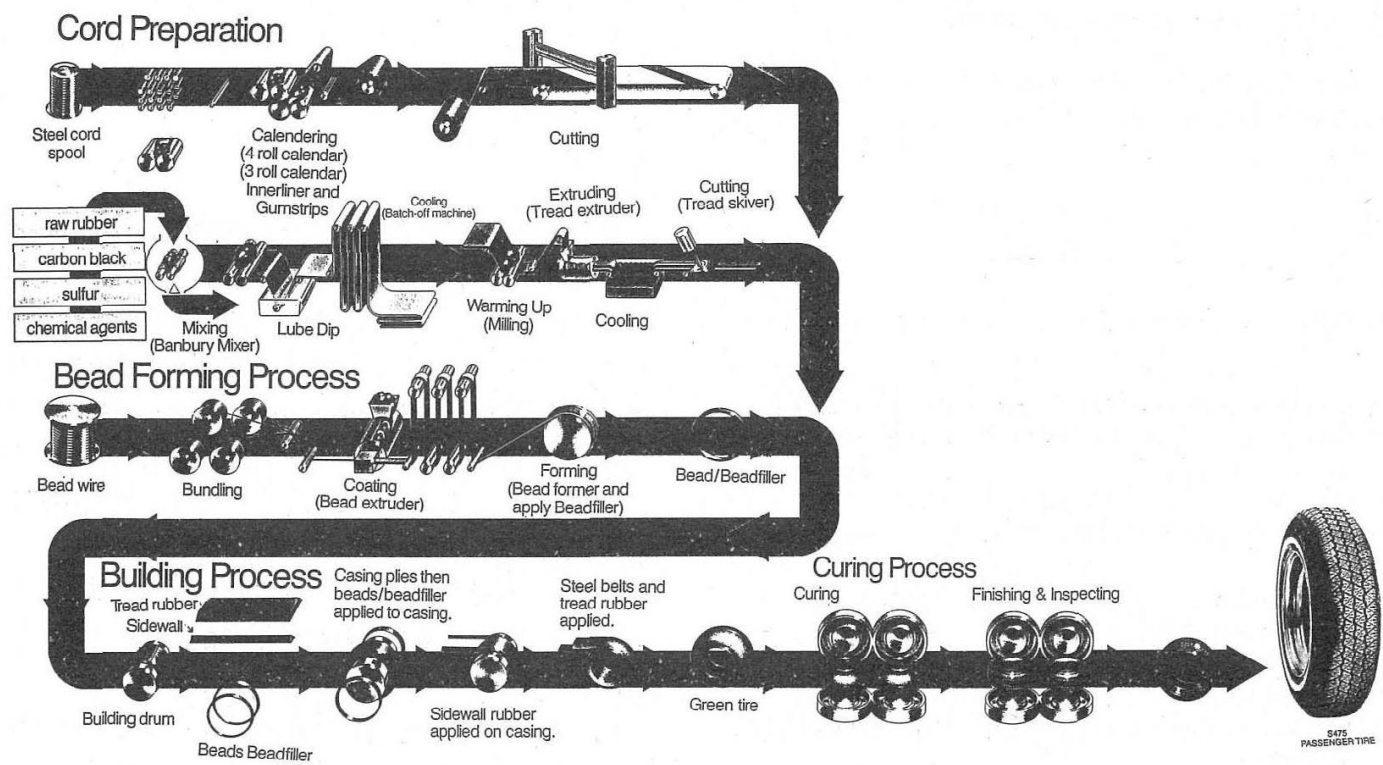

Fig. 1 A typical tire manufacturing process 
界とは, 一般につぎのものがあげられている4).

（1） シーケンスの働きがラダー図の中に埋没してしま う. 順序制御やインターロックなどがすべて接点と コイルで表現されるので, 設計した人以外にはわか らず，メンテナンスがむずかしい.

（2）仕様とシーケンスの対応がわかりずらい.

（3） シーケンスの構造化プログラミングができない. 上位レベルからトップダウンに展開して設計するよ うなことができない.

(4) 簡単な算術演算やデータ処理はファンクションブ ロックとしてラダー図に取り込むことはできるが， 今後必要になる高度のデー夕処理はむずかしい.

\section{2 シーケンス制御の解釈}

\section{2 .1 ラダー図方式の動作}

ここで，シーケンス制御をいかに効率よく行うかの理 論的考察を試みる。シーケンス制御における入出力状態 の変化は, 入力が変化することによって出力が変化しリ レーやソレノイドといったアクチュエータを駆動し，そ の機械的動作の結果をセンサなどにより入力の変化とし てフィードバックされる.一般にサイクリックに実行す るシーケンス制御装置の動作は，（1）式で表現される4).

$$
O(K+1)=f(O(K), I(K))
$$

$O$ はシーケンス制御装置の内部状態量(ベクトル), $I$ は シーケンス制御装置の入力(ベクトル)で, それぞれ 0 あ るいは 1 の值をとる. $K, K+1$ はシーケンス制御装置の 処理周期を示す。（1 ) 式を論理行列で表わすと (2) 式と なる。

$$
\left[\begin{array}{c}
O_{1} \\
O_{2} \\
\vdots \\
\vdots \\
\vdots \\
O_{m}
\end{array}\right]_{K+1}=\left[\begin{array}{ccccc}
F_{11} & F_{12} & F_{13} & \cdots \cdots & F_{12}^{m+n} \\
F_{21} & F_{22} & F_{23} & \cdots & F_{22}^{m+n} \\
\vdots & \vdots & \vdots & & \vdots \\
\vdots & \vdots & \vdots & & \vdots \\
\vdots & \vdots & \vdots & & \vdots \\
F_{m 1} & F_{m 2} & F_{m 3} & \cdots \cdots & F_{m 2}^{m+n}
\end{array}\right] \cdot\left[\begin{array}{c}
O_{1} \\
O_{2} \\
\vdots \\
\vdots \\
\vdots \\
O_{m} \\
I_{1} \\
I_{2} \\
\vdots \\
\vdots \\
\vdots \\
I_{n}
\end{array}\right]_{K}
$$

(2) 式の $F_{i j}$ は, 論理行列(Boolean Matrix) と呼ばれ, $O, I$ のすべての組合せ $2^{(m+n)}$ 通りの入力に対して, つぎ の新しい $m$ 個の出力 $O$ がどのような值をとるかすべて を書き表わしたものである.
出力 $\left[\begin{array}{c}O_{1} \\ O_{2} \\ \vdots \\ O_{m}\end{array}\right]$ は, $\left[\begin{array}{c}F_{11} \\ F_{21} \\ \vdots \\ F_{m 1}\end{array}\right],\left[\begin{array}{c}F_{12} \\ F_{22} \\ \vdots \\ F_{m 2}\end{array}\right], \cdots \ldots\left[\begin{array}{c}F_{12}^{m+n} \\ F_{22}^{m+n} \\ \vdots \\ F_{m 2}^{m+n}\end{array}\right]$ のいずれ かの列ベクトルをとることを表わしており，通常の行列 演算式とは異なる.たとえば, 入力 10 個, 出力 10 個の シーケンス制御では, 論理行列の要素数は非常に大きく, $2^{20} \times 10=10,485,760$ となる ${ }^{4), 6)}$. ラダー図による表現は, 論理回路図として記述された接点, コイル, 入出力信号 すべての要素の情報を常時, 無条件(起こりうるか否かの 可能性の議論をせず）にスキャンする方式をとっている ため効率が悪い.これに対し, 状態遷移の条件として着 目しなければならない条件を書き連ねていくことで, シーケンス動作が記述できれば理想的である.

\section{2 .2 フローチャート方式の動作}

一般的には (2) 式で全ての入出力が表現されるが，実 際の機械は, 独立したアクチュエー夕機構の組合せより 成り立っている.すなわち，それぞれのアクチュエータ 機構ごとの論理行列を組み合せることによって全体の論 理行列を構成することが可能となる.(3), (4) 式におい て, $\mathrm{I}, \mathrm{O} i$ は列べクトルで, 要素数はそれぞれ $n^{\prime \prime}(\leqq n)$, $m^{\prime \prime}(\leqq m)$ である. $\boldsymbol{F} i$ は, $\boldsymbol{I} i, \boldsymbol{O} i$ により決まる論理行列 で, $1 \leqq i \leqq m^{\prime}$ である.

ここで注目すべき点は，実際の機械はシーケンス制御 が対象とする全ての入出力の組合せのうち，ごく限られ た数少ない遷移条件によって動作しているという事実で ある(たとえば, 機械の動作は, 押ボタンの入力一つのト リガーで停止状態から簐転状態に切り替わるなど).つま り，(4)式において常にすべての入出力の情報を監視す るよりも, あらかじめ注目すべき(起こりうる可能性のあ る)移行条件のみを記述して監視しておけば,より効率的 にシーケンス制御の処理が可能であるといえる8).この ような記述に近いプログラミング方式の一つがフロー チャート方式である.

$$
\begin{gathered}
{\left[\boldsymbol{O}_{1}\right]_{K+1}=\boldsymbol{F}_{1}\left[\begin{array}{l}
\boldsymbol{O}_{1} \\
\boldsymbol{I}_{1}
\end{array}\right]_{K}} \\
{\left[\boldsymbol{O}_{2}\right]_{K+1}=F_{2}\left[\begin{array}{l}
\boldsymbol{O}_{2} \\
\boldsymbol{I}_{2}
\end{array}\right]_{K^{\prime}}} \\
\vdots \\
\vdots \\
{\left[\boldsymbol{O}_{m^{\prime}}\right]_{K+1}=\boldsymbol{F}_{m^{\prime}}\left[\begin{array}{l}
\boldsymbol{O}_{m^{\prime}} \\
\boldsymbol{I}_{m^{\prime}}
\end{array}\right]_{K}}
\end{gathered}
$$




$$
[\boldsymbol{O}]_{K+1}=\left[\begin{array}{cccccc}
\boldsymbol{F}_{1} & \boldsymbol{\Phi} & \cdots & \cdots & \boldsymbol{\Phi} & \boldsymbol{\Phi} \\
\boldsymbol{\Phi} & \boldsymbol{F}_{2} & \ddots & & \boldsymbol{\Phi} & \vdots \\
\vdots & & \boldsymbol{F}_{3} & \ddots & \vdots & \vdots \\
\vdots & & & & \boldsymbol{\Phi} & \vdots \\
\boldsymbol{\Phi} & \cdots & \boldsymbol{\Phi} & \boldsymbol{F}_{m^{\prime}} & \vdots \\
\vdots & & & \ddots & \boldsymbol{\Phi} & \boldsymbol{\Phi} \\
\boldsymbol{\Phi} & \cdots & \cdots & \cdots & \boldsymbol{\Phi} & \boldsymbol{\Phi}
\end{array}\right]\left[\begin{array}{c}
\boldsymbol{O}_{1} \\
\boldsymbol{I}_{1} \\
\boldsymbol{O}_{2} \\
\boldsymbol{I}_{2} \\
\vdots \\
\vdots \\
\vdots \\
\vdots \\
\vdots \\
\\
\end{array}\right.
$$

$\Phi:$ don't care

\section{3 ラダー図に代わるプログラミング言語の選定}

ラダー図方式以外の PC プログラミングとしては, 論 理図記号方式，ブール代数方式，マトリクス・テーブル 方式，フローチャート方式などが実用化されている ${ }^{4)}$. 前節のシーケンス制御の効率的な記述の考察より，なか でもフローチャート方式は今後ラダー図に代わる有望な 方式と考えられる.その代表的な SFC は，フランス国内 およびヨーロッパで実績がある GRAFCET (Graphic de Commande Etape-Transition)をべースに改良と規格 化を図ったものである。最近，IEC(International Electro-technical Commission)で規格化された SFC が，いくつかの PCメーカから提供されている4),5).

このような背景のもと, 著者らは, 1985 年より $\mathrm{SFC} を$ ラダー図に代わる次世代のプログラミング言語として採 用し，タイヤ製造ラインに適用するための研究開発を 行ってきた1),2).

当初，ラダー図方式と SFC との比較を行った結果を Table 1 に示す ${ }^{1)}$.この表からわかることは, ラダー図は, 機械の条件，インターロックの表現で優れるもののシー ケンス動作の表現では SFC に劣ること，また，3.1節で

Table 1 Advantage and disadvantage between Ladder Diagram and SFC

\begin{tabular}{|c|c|c|c|}
\hline \multicolumn{2}{|r|}{ Language } & Ladder & SFC \\
\hline \multirow{2}{*}{ 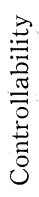 } & $\begin{array}{l}\text { Condition } \\
\text { \& Interlock } \\
\text { (CI) Logic }\end{array}$ & (0) & $x$ \\
\hline & $\begin{array}{l}\text { Sequential } \\
\text { Control }\end{array}$ & & (O) \\
\hline \multicolumn{2}{|c|}{ Maintenability } & $x$ & (O) \\
\hline
\end{tabular}

( ) : VERY GOOD $\bigcirc:$ GOOD $X:$ POOR
あげた限界のようにプログラムの保守性に問題があるこ と. 一方，SFCは，これらラダー図方式の欠点をカバー していること.しかし，条件やインターロックの表現に おいてラダー図方式に劣ることなどである。ここで注目 すべき点は，条件的制御を除けば， SFCは従来のラダー

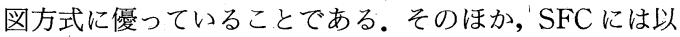
下の興味あるメリットが期待できる ${ }^{10), 11)}$.

（1）動作の直接的表現のため，見やすく誰でも理解で きる。

（2）保守，修正，改良が容易である.

（3）プログラムのドキュメントがコンパクトで明解で ある。

（4）動作の移行条件のみ処理するため PC の負荷が下 がる。

\section{SFC 実用上の問題点}

\section{$4.1 \mathrm{SFC}$ 応用上の問題点}

$\mathrm{SFC}$ は，制御あるいは機械の動作をプログラムのフ ローとして実行順序に従い記述していくため, 順序動作 のプログラミングは容易である。しかし, SFC は, 条件 やインターロックといつた常時監視が必要な事象のプロ グラミングには向いていない.もし，監視しようとすれ ば，常時ループするフローを作り条件を判定する必要が ある.これでは, 負荷やほかの動作への悪影響のほうが目 立つ結果となってしまう。実際，当初のアプリケーショ ン例では, 常にこの問題が議論された. たとえば, 状態 表示のランプを点灯させるといつた機能でさえ負荷が高 くなるため, 数を制限しなければならなかった ${ }^{1), 21}$

\section{2 ハイブリッド SFC による問題点解決の提案}

人間の挙動に似通った動作モデルにこの問題の解決の 糸口があった.たとえば，人が目の前のコップに手をや るとき，意識的にはただ「飲む」という意図しか働いて いない.しかし，コップが非常に熱い場合には，無意識 で出した手を引つ込める行動にでる．ここでは，順序的 な計画された動作は意識的に逐次制御対象に命令を与え ることによって遂行される. しかし，いったん危険な状 態を察知した際は，とっさに無意識の制御が優先的に機 能し危険を回避する仕組みが働く.

機械の制御においても同様な機能が不可欠で, 非常停 止，予期せぬ停電などの異常事態には即対応しなければ ならない.このような制御機能は，従来のラダー図によ るシステムにおいても必ず考慮されている，この条件判 断・インターロックの機能 (CI 機能 : Condition and Interlock 機能)が SFCの最も不得意とする機能であ り, SFC 応用上の問題もここに起因していることがわ かった。 
この点に着目し，このCI 機能だけをラダー図方式の 形で残し，あとは SFCで記述するという八イブリッド $\mathrm{SFC}$ により, SFC の問題点を解決した。これにより, Table 1 に示す SFC の欠点が, ラダー図方式によって補 われる1,22.

\section{5. 制御装置の概要}

\subsection{SFC 用 PC の構成}

Fig. 2 亿 SFC をのせた PC のハードウェア構成を示 す。使用した PC は，(株)日立製作所製のシーケンサ(型 式：HIDIC S 10/2 $\alpha$ ), ソフトウェアとして同社の SFC (HI-FLOW) を使用した。この PC の特徴は, SFC を専 用に処理するプロセッサとメモリ，ラダー図を専用に処 理するプロセッサとメモリをそれぞれ独立に配置し，そ れらが有機的に機能するようお互いのメモり間の情報を やり取りする中間レジスタを設けている点である7).

Fig. 3 亿その中間レジスタの情報のやり取りの方法を 示した。 それぞれ一方向性の $J, Q$ レジス夕( $J$ は $S F C$ か らラダー図へ, $Q$ はその逆の方向に使用)によって, 二つ の制御機能がお互い連携して動作する仕組みになってい る. 具体的なプログラム上での情報のやり取りの様子を Fig. 4 に示す.

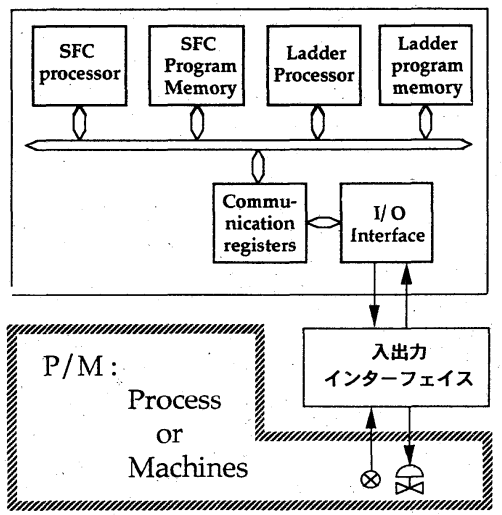

Fig. 2 General hardware configuration of PC

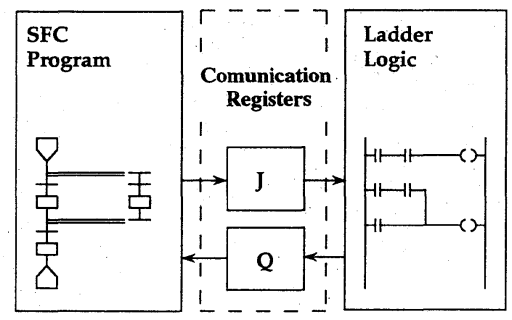

Fig. 3 Comunication Registers

\section{2 応用例}

ハイブリッド SFC は,タイヤ製造工程の機械制御に応 用し, 現在 100 台以上の機械に使用されて稼働している. そして, 機械の種類では 10 種以上の応用事例において, その効果が評価されている.

Fig. 5 に代表的な応用例を示す.このシステムは, タイ ヤのハンドリング装置で，コンベヤとシリンダで構成さ れている.タイヤは 1 本ずつ運ばれ，各ステージで処理 され，最後のステージで自動的に積み上げられ格納され る.Fig. 6 にこの装置のプログラムの一部を示す. 図中に おいて，中間レジスタを介して通信している一例を破線 にて示した(SFC からの動作指示が JO89レジスタを介 してラダー図側へ送られている).

ハイブリッド SFC においては, SFCにより機械の動 作順序が記述され，ラダー図では条件とインターロック のみが記述されている，これまで，ラダー図の繁雑さの 大きな要因であった自己保持回路による順序記述はこの ラダー図からなくなっている，そして，両者は特別に設 けられた中間レジスタ $(J, Q$ レジスタ)によって制御信 号のやり取りが行われている11,2).

たとえばFig. 4 において, SFC は機械が設計されたと

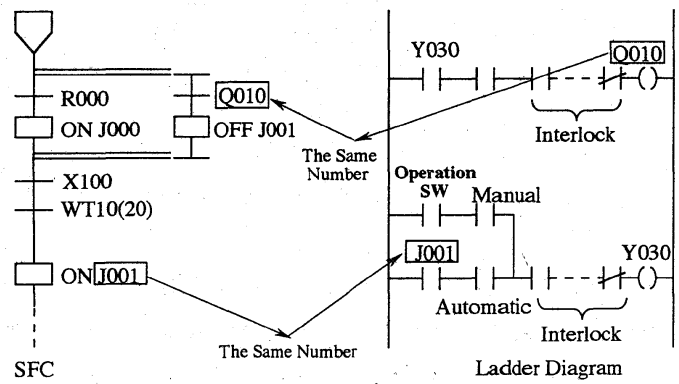

Fig. 4 An example of programming using communication registers

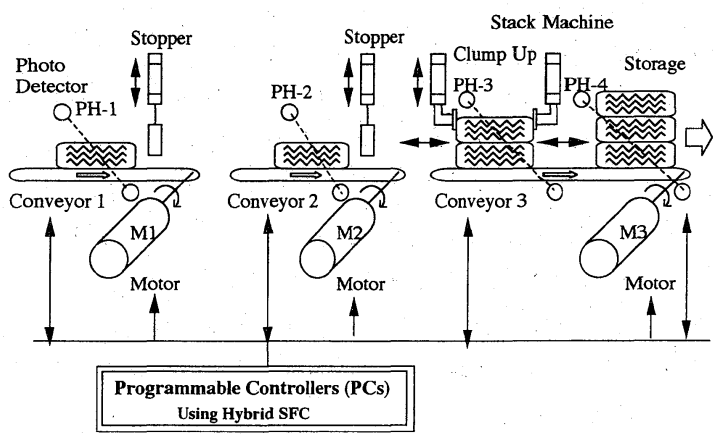

Fig. 5 An example of practical application in a tire manufacturing process 


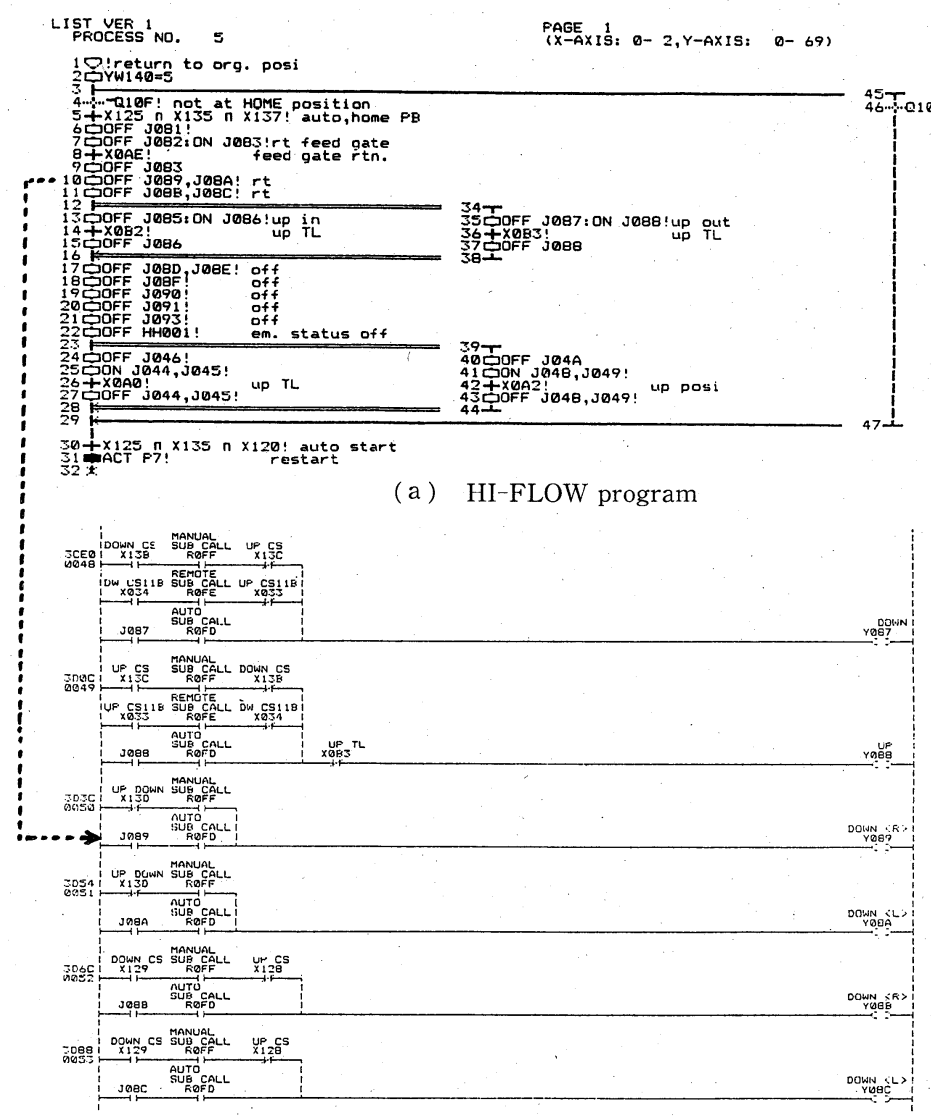

(b) Ladder Logic

Fig. 6 A practical example of Hybrid SFC and Ladder in Fig. 5 application

おりの順序に従い, Jレジスタによって指示をラダー図 側に逐次与える。そして，指示を受け取ったラダー図側 は, インターロック条件を保証しながらアクチュエータ に出力信号を出す．仮に，アクチュエータ駆動の途中で インターロックや非常停止の事態になっても, ラダー図 側で停止操作の処理が行われ，SFC 側は単にアクチュ エータの動作完了(ラダー図側から $Q$ レジスタで与えら れる条件)待ちの状態を維持するだけである.

このような制御機能分担の仕方により，インターロッ クと順序動作とは相手側を意識しないで別々に設計で き,さらに条件・インターロック用ラダー図に単動用の スイッチ入力回路さえ組み込めば(たとえば，Fig. 4 の “Operation SW”), 試運転調整作業も SFCのプログラ 厶作成を待たずに独立して先行することが可能である. この分業化によって現場の調整期間が短縮でき，試運転 の効率を上げることができる。

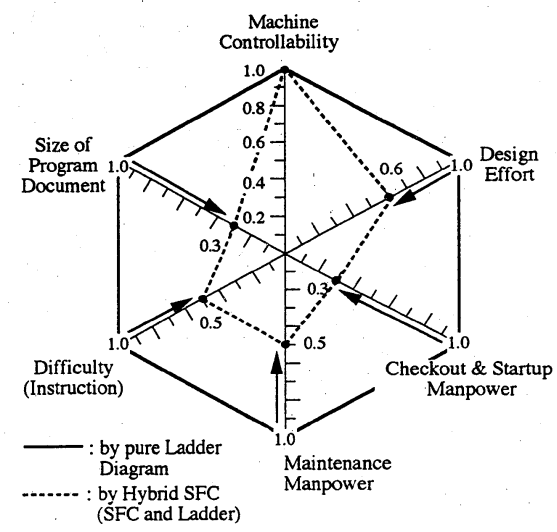

Fig. 7 Evaluation of Hybrid SFC and pure Ladder Diagram 


\section{6. 評価と考察}

\section{1 ハイブリッド SFC の評価}

現在までの応用結果の評価を Fig. 7 に従来のラダー 図方式のみの応用結果との比較として,レーダーチャー トを用いて示した。このチャートは，制御的な機能を従 来のラダー図方式のみで実現した場合と今回のハイブ リッド SFCで同等(図中，機械制御性で，ともに $100 \%$ =1.0)で実現した場合の比較である. 各評価項目におい てつぎの結果を得た。

（1）設計工数において，30\%削減できた。

（2）試運転工数において，60\%削減できた。

（3）保全工数において，50\%削減できた。

（4）教育工数において，50\%削減できた.

（5）プログラムの文書量に扔いて，70\%削減できた。 ハイブリッド SFC を採用することによって, SFC と ラダー図の各欠点を補えるだけでなく，さらにいくつか の予想しなかった相乗効果を引き出すことができる。そ れらの相乗効果とは,

（1）順序制御と条件・インターロックの設計，試運転 が分業可能となることで設計，試運転工期が短縮で きる.

（2）両者の記述の無理な部分が減少し，単純で直接的 な表現となる結果, プログラムの個人差も少なくな る.

（3）個人芸的な技術，ノウハウが不要となった結果， 設計, 保全要員の育成が短くでき，専任者も不要と なる.

（4）明解な記述のため，機械動作に関するプログラム

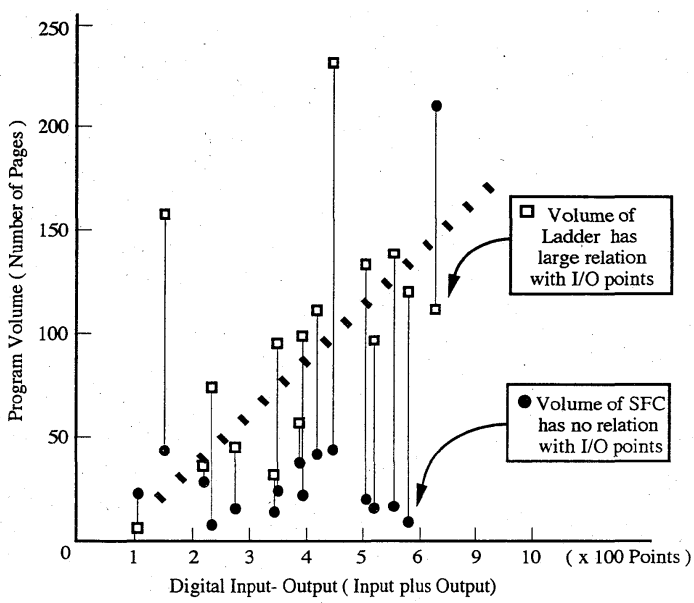

Fig. 8 Program volume versus number of $\mathrm{I} / \mathrm{Os}$ in $\mathrm{SFC}$ applications
上の問題点を機械,製造技術者と共用可能となった.

（5）機械動作上機密部分 (順序記述) と CI 機能といっ た機密性の低い部分が区別でき，設計外注可能範囲 を増やすことができる。

\section{$6.2 \mathrm{SFC}$ ，ラダー図のプログラム量}

Fig. 8 にこれまでのハイブリッド SFC の応用例にお いて，機械ごとに SFC (動作順序記述)，ラダー図 (CI 機 能)それぞれのプログラム量を示した.ここで興味深いの は, ラダー図のブログラム量は, ほぼ設備の規模(入出力 点数)に比例しているのに対して, SFCのプログラム量 は設備の規模に何ら相関を示していない点である。これ は, CI 機能を表わすラダー図が入出力, 特にアクチュ エータの個数に比例しているからである．また，動作順 序を記述する SFC のプログラム量は, 純粋に設備の動き の複雑さを忠実に反映している.たとえば, Fig. 8 のなか で二つの設備において SFC のプログラム量が, ラダー図 のそれを上回っているが，この設備は動作パターンの種 類が比較的たくさんプログラムに含まれているものであ る。

従来のラダー図方式のみの場合，作成者の能力や流儀 でプログラム量が変化し，その量の妥当性は入出力の点 数から類推するしかなかった。これに対して,ハイブリッ ド SFCにおいてはその記述に圥長的要素があまりなく， 必要な機能を相応のプログラム量で表現されているとい うことになる。

\section{7. まとめと今後の課題}

$\mathrm{SFC}$ 従来のラダー図と組み合せたハイブリッド $\mathrm{SFC}$ によって, 両者の欠点を補い, 長所を引き出すこと に成功した。この方式により，現在 PC 用の制御プログラ ミング言語であるラダー図における能力的限界としてあ げられている多くの問題点解決へのめどがたつた.夕イ ヤ製造工程においてこの方式を応用し，10 種類，約 100 台以上の実施例からその効果を確認できた。この方式を 活用したシーケンス制御をタイヤ製造工程に広める運動 を展開中である。

今後の課題としては,この手法におけるソフトウェア とハードウェア的制約をなくし，応用の範囲を広めるこ とである.ソフトウェア的制約としては, SFCの弱点を 補うのに従来のラダー図方式を採用しなければならない かという点である。これに対しては，ラダー図に固執す る制約はなく，条件・インターロックを記述するのに適 した表現であれば十分である，たとえば，ブール代数表 現，ロジックシンボル的表現などを用いても等価な条件 記述が可能である.プログラミングを行う人の得意な表 現形式を採用すればよいと考えられる．八ードウェア上 
の制約としては, PC に SFC,ラダー図專用プロセッサを 備えることの必要性である。PCのプロセッサの演算速 度がさらに遠くなれば，一つのプロセッサで SFC と CI 機能用のラダー図を同時に動作させても制御上問題がな くなる。また逆に, SFCを使うことによる負荷の低減効 果が期待できるため，この手法をすでに多く存在する多 くの PCで試してみる価値があると考える。

$\mathrm{SFC}$ は，フローチャート形式というその本来の特長か ら，機械の状態とプログラムの進行状況が一致している ため, 設備の状態診断や過去の事象のトレースも可能に なるなど，ラダー図では不可能であったことがいろいろ 現実性を帯びてくるものと期待される。

本論文の内容が, SFC を応用したシーケンス制御技術 の発展に役立てば幸甚である。

\section{参 考 文 献}

1) T. Kokubu, et al: Application of Powerful SFC Language (HI-FLOW) to FA Systems in a Tire Industry, Proceedings of IECON'90, I 586/591(1990)

2) T. Kokubu, et al: Enhancement of the HI-FLOW (SFC Language) to Efficient FA Systems in the Tire Industry, Proceedings of IECON'92, II, 880/885(1992)

3）本田, 坂田, 奥：タイヤ製造工程, オートメーション, 33-1, 31/35(1988)

4）関口 隆：シーケンス制御システムの表現法, オートメー ション, 32-7, 9/14(1987)

5) IEC 1131-3 : Programmable Controllers Part 3, Programming Languages: IEC (1993)

6) 関口 隆：シーケンス制御工学, 電気学会, 123/124(1988)

7) K. Matsuzaki, et al: Programmable Controller with a Microprocessor-Based High Speed Interactive Language System, Proceedings of IECON'83, 180/185 (1983)

8) J. G. Bollinger and N. A. Duffie, : Computer Control of Machine and Process, Sequential Control Using Programmable Logic Controllers, Addison-Wesley (1993)
9) O. J. Struger and J.H. Christensen, : Language for Programmable Controllers, Conf. Rec. IEEE IAS Annual Meeting, 17, 1261/1265(1957)

10) J. L. Peterson: Petri-Net Theory and the Modeling of Systems, Prentice-Hall, NJ (1981)

11) A. Falcione and B.H. Krogh: Design Recovery for Relay Ladder Logic, IEEE Control Systems, 13-2, 90/ 98(1993)

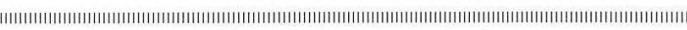

\section{[著 者 紹 介]}

國 分 孝 夫 (正会員)

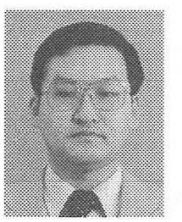

1979 年, 慶應義塾大学工学部計測工学科 卒業。同年(株)ブリデストン入社。 87 年豊 田工業大学大学院修士課程修了.現在, (株) ブリデストン電気制御開発部において，生 産設備の制御技術開発に従事. IEEEの会 員。

\section{神 山 健 三（正会員）}

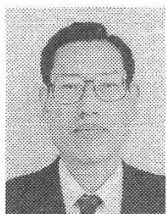

1961 年, 早稲田大学大学院修士課程修 了。同年(株) 日立製作所入社. DC および $\mathrm{AC}$ モータドライブ装置の研究開発に従 事。91 年宇都宮大学工学部教授 (工学博 士). 80 年 IEEE Best Paper Award を受 賞。電気学会, IEEE などの会員。

浜 野 順 一 (正会員)

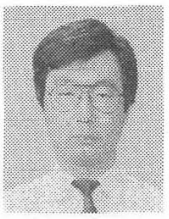

1980 年, 東海大学工学部制御工学科卒 業. 82 年同大学大学院修士課程修了. 同年 (株) 日立製作所入社。現在, 同社生産技術 研究所において，FA システムおよびその 言語の研究に従事. 電気学会の会員。

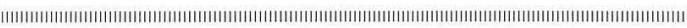

